\title{
Economy and planet: a blind spot for community psychology?*
}

\section{Economía y planeta: iun punto ciego para la psicología comunitaria?}

Enviado: 1을 marzo de 2015 | Revisado: 1ํ de junio de 2015 | Aceptado: 1o de agosto de 2015

\author{
MARK BURTON ** \\ Steady State Manchester and Manchester Metropolitan \\ University, Inglaterra
}

doi:10.11144/Javeriana.upsy14-4.epbs

Para citar este artículo: Burton, M. Economy and planet: a blind spot for community psychology? Universitas Psychologica, 14(4), 1339-1346. http:// dx.doi.org/10.11144/Javeriana.upsy14-4.epbs

* Artículo de reflexión. Colleagues from Steady State Manchester and the editors of this special issue. Colegas de Steady State Manchester y los coordinadores de este numero de la revista.

** Correo electrónico: mark.burton@poptel.org

\begin{abstract}
A B S T R A C T
Conventional economics shares a number of characteristics with mainstream psychology: individualism, acontextualism, and both social and ecological irrelevance. Community psychology has been one response to the shortcomings of mainstream psychology, but has not typically engaged with criticisms of the conventional economics with which it shares assumptions, nor with the economic dimension of community. I reflect on experience promoting alternatives to the dominant economic growth / global competitiveness policy paradigm in the region of Manchester, England, and on the community psychological nature of this project. Community psychology can help articulate an alternative set of values and provide conceptual and practical tools for counter-hegemonic social movements, but the path from community psychology praxis to social movement praxis is not obvious.

\section{Keywords}

economics, ecology, social movements, community psychology
\end{abstract}

\section{RESUMEN}

La economía convencional comparte varias características con la psicología tradicional: individualismo, acontextualismo, e irrelevancia social y ecológica. La psicología comunitaria ha sido una respuesta a la psicología tradicional pero no ha considerado la crítica a la economía convencional, con la que comparte supuestos, ni la dimensión económica de las comunidades. Reflexiono sobre la experiencia de promover alternativas al paradigma dominante, centrado en el crecimiento económico y la competitividad global, en Manchester, Inglaterra, y sobre el aspecto psico-comunitario de este proyecto. Aunque la psicología comunitaria puede ayudar a articular valores alternativos, proporcionando herramientas conceptuales y prácticas para los movimientos sociales contrahegemónicos, el camino desde la práctica de la psicología comunitaria hasta la de los movimientos sociales no es evidente. Palabras claves

económica, ecología, movientos sociales, psicología comunitaria 
I live in Manchester, the first industrial city, the home of the free trade movement in the $19^{\text {th }}$ Century, but also of the co-operative movement, and the city where Frederick Engels conducted his research on the capitalist system. There are several Universities, among them the University of Manchester, one of the world's most highly rated, with a lot of competition for places. There, the highly selected and very able students have begun to ask questions. Why did the economics they were being taught not cover the events of the last 7 years, when the global financial system nearly collapsed, and millions of people experienced economic hardship. And why were they still being taught economic theory and methods that had so obviously failed to predict the financial crash? The movement they started has spread nationally and internationally, and shaken the academic economics establishment.

I will return to Manchester but first I want to look at the characteristics of the neoclassical economic theory that dominates the economy curriculum in most Universities.

\section{Neoclassical economics - the first cousin of traditional psychology}

Neoclassical economics is the name given to the approach. It is not the same as neoliberalism, although there is an overlap. Neoclassical economics is the technical discipline while neoliberalism is the ideology, and the set of political and policy prescriptions such as rolling back the state and bringing market mechanisms into all areas (Davies, 2009). Not all neoclassical economists are neoliberals, though many are, and neoclassical economics, because of its central assumptions generally supports neoliberalism.

The assumptions of neoclassical economics are interesting, because they are similar to those of conventional, empiricist psychology. Arnsperger and Varoufakis, in a much cited article (2006), identify three key assumptions:

1) Methodological individualism: the idea that socio-economic explanation must be sought at the level of the individual agent, in terms of their action, or agency, "imposing a strict separation of structure from agency, insisting that socio-economic explanation, at any point in time, must move from agency to structure, with the latter being understood as the crystallisation of agents' past acts" (p. 2).

2) Methodological instrumentalism: "All behaviour is [...] to be understood as a means for maximising preference-satisfaction." (p. 3). Note that this does not necessarily mean all people and actions are rational, but they are to be modelled as if they were. And despite increasing sophistication of neoclassical economics, "homo economicus is still exclusively motivated by a fierce means-ends instrumentalism. He may have difficulty defining his ends, without firm beliefs of what means others expect him to deploy, but he remains irreversibly ends-driven". (p. 3).

3) Methodological equilibration: the central point of reference is 'What behaviour should we expect in equilibrium?'. Whether an equilibrium is likely is not questioned: the concern is with perturbations from the equilibrium and the tendency to return to that state.

This meta-theoretical model has led to a practice of economics based on the rational, autonomous individual, making choices. Its conceptual models ignore the wider context of ecology and society. It ignores the collective dimension, and those aspects of human life (such as domestic work) that are not subject to monetary exchange. And its models were shown to be of staggering incompetence when the global economy tumbled - only a handful of economics professionals predicted the crash. But the orthodox teaching goes on, with its quantitative models that bear little resemblance to the real world of human life in a finite world.

\section{Planet and economy: community psychology's blind spot}

To a psychological audience, these assumptions will appear eerily familiar, for they are those that underpin much mainstream, individualistic, empiricist psychology. Orthodox psychology similarly likes to build models based on the individual level, better if they are quantitative. It ignores the making of humans through their transactions in soci- 
ety via family, economy and community. It can be hopelessly irrelevant when confronted with the real challenges facing humanity-war, exploitation, ecological collapse. Much of this was said in the late 1960s and 1970s and that debate helped pave the way for both community social psychology and liberation psychology.

Indeed, the critiques of that dominant model, from community, critical and liberation psychologies generally take issue with these assumptions and with a way of doing psychology that treats people as isolated islands, self-interested and without social conscience or consciousness. But these alternative psychologies have not generally engaged with either the critique of economic thought, or the economic dimension of community.

\section{Escaping the economy: community psychology and alternatives}

Beyond this, today's complex of social, ecological, economic and ethical crises, is connected to the endless pursuit of economic growth in a global economy, underpinned by capital accumulation, expropriation and the ever-increasing burning of fossil hydrocarbons. Critical responses to the damaging prioritisation of endless economic growth have emerged both in the academy, for example work on alternative measures of economic social well-being (Anderson, 1991; O’Neill, 2012), and ecological economics (Daly \& Farley, 2011; Jackson, 2011), and from social movements, for example the decroissance / decrecimiento / degrowth and post-growth movements in the global North (D'Alisa, Demaria, \& Kallis, 2014; Latouche, 2012b) and the ecologically orientated social and solidarity economy, de-colonial / vivir bien and peasant movements of the global South (Fatheuer, 2011; Huanacuni Mamami, 2010). But what, if anything, does community psychology have to say about this, and can it help those working for a just and safe society and economy?

If we consider the influences on communities and community life, we might identify the following:

- Internal aspects of community

- Tradition and culture
- Social Policy

- Local politics

- Employment

- Costs and prices

- Scarcity versus abundance / security

- Sovereignty - e.g. food, energy

Clearly the majority of these have economic and ecological aspects, yet community psychology almost universally ignores these two fundamental bases for community life and well-being. It could, however make a considerable contribution to transformation towards an economy that enables people to thrive without harming the planet.

The potential contribution of Community Psychology can be considered under the following headings:

Articulation of another vision and model of social life - a true escape from the economy

Our own approach to community psychology (Kagan, Burton, Duckett, Lawthom, \& Siddiquee, 2011) has long argued for the central role of a prefigurative approach, to both social action and investigation (Kagan \& Burton, 2000). This is in large part a response to the fragmentation of mesolevel initiatives, that fail to be brought together as learning and action, remaining no more than the sum of their parts. Our quest here is to connect the alternative modes of living a culture of solidarity and stewardship that emerge at the community level (Kagan \& Burton, 2014), with large scale social and political movements for social change. This cannot be done by a community psychology that restricts its mission to 'research on communities' or to merely local action to ameliorate conditions, without focusing on the generative forces for injustice and destruction. By "escape from the economy" we are borrowing a term from Latouche (Latouche, 2012a), who echoes Gorz (2010) in drawing attention to the domination of an economic rationality wherein economic criteria take precedence over other dimensions of human life (see also Hinkelammert \& Mora Jiménez, 2005; Smith \& Max-Neef, 2011). 
Contribution to the understanding

of the institutional, ideological

and social-psychological barriers

to making fundamental changes

to the global economic system

There are multiple barriers to redesigning and installing an alternative global economic system founded on justice and stewardship. The problem is that the system is self-reinforcing, with its political, ideological, economic and legal subsystems working together (Harvey, 2010). These then constrain the thinking and action of those who stand to benefit from changes, entering into their own lives, their thinking, commitments, dependencies and relationships. However, community psychology (or at least the more critical and liberation orientated variants) has a good understanding of these processes, and of the processes of problematisation, conscientisation and de-ideologisation. Its practitioners can intervene at a variety of levels, exposing the mechanisms of economic domination and identifying ways of combating them (Walker, Burton, Akhurst, \& Degirmencioglu, 2014; Walker $\&$ Degirmencioglu, in press).

Contribution to understanding the impacts of economic and ecological injustice on those most affected

Because community psychologists tend to operate at the micro and meso levels, engaged with communities who experience disadvantage, they are in one of the best positions to document and expose the impacts of the current system on those most affected. However, since the system operates internationally, with major expropriations of wealth from region to region (Amin, 2010; Chossudovsky, 2004), it is essential that connections are made among practitioners in diverse locations, overcoming the particularism of location. At the same time, the co-existence of diverse forms of exploitation across the globe and within all countries also needs to be understood and explained (Grosfoguel, 2008). But in this process, the publication of articles in outlets only read by other psychologists is inef- fective in movement building - it is essential, not only to share the understandings generated with other audiences, but to build those understandings with them, for example with those most involved and with anti-poverty campaigners (e.g. Kagan et al., 2011).

Assistance to activists and social movements fighting for economic and ecological justice

Denouncing a system that is oppressive, ubiquitous and ruthless is not easy. Nor is it easy establishing and defending prefigurative alternatives and alternative policies and designs. The system pins us down in many ways, infecting even the way in which we contest it. Can social psychology offer anything to maximise the effectiveness of social movements and their activists? Can it help those movements to create psychologically healthy spaces for action? Community psychology does not have a monopoly on theory and practice here, but it can make a humble contribution, as it has from time to time when approached specifically by activists seeking help with things like group dynamics and leadership processes (Kagan, Lawthom, Knowles, \& Burton, 2000; Mendoza, J \& Zerda, M, 2011; Sánchez, Cronick, \& Wiesenfeld, 1988).

But while insights from community psychology can help articulate an alternative set of community-orientated values and provide conceptual and practical tools for counter-hegemonic social movements, the path from community psychology praxis to social movement praxis is not obvious, and there are relatively few examples where this has occurred.

\section{An example}

To finish I would like to reflect briefly on my own experience as a scholar-activist promoting alternatives to the dominant economic growth / global competitiveness policy paradigm in the city and region of Manchester, England, and on the community psychological nature of this project. I have been able to get involved in this work since retiring from a role in human services, and although it is useful to have a University affiliation and title, the 
academic and professional world of psychology has no involvement in this work.

Our project aims to explore and spell out what a post-growth economy and society would mean in a municipal and regional context and to build support for its proposals. We aim to make this approach, which aligns ecological, social and economic wellbeing, a part of everyday understanding - a new common sense.

Our context is challenging because our municipal and regional leaders subscribe to the economic growth orthodoxy, linked to a version of 'trickledown theory, whereby it is argued that growing the economy, largely by attracting external capital investment via prestige projects, will increase incomes and social benefit for all, including the disadvantaged sections of the community. This view is linked to the model of competition in a global economy, to promotion of the city ("civic boosterism" or more recently "aglommeration boosterism", Haughton, Deas, \& Hincks, 2014) and to the extent that it pays attention to ecological problems it does so via what has been termed "ecological modernisation" where the primary argument becomes that of building a green economy in order to further create growth (Deloitte, 2008): again, it is an economic rationality that dominates (Burton, 2013). Despite this there is an undercurrent of dissatisfaction, since people know that the model is flawed, that it does not deliver genuine prosperity, but instead increases inequality and has a high ecological cost.

As a small collective of five people, we have to work via other organizations, groups and people to have the maximum effect (leverage). That involves appealing to people's values (e.g. social justice), colonising dominant discourse (e.g. an emerging discourse about good vs. bad growth (Henderson \& Capra, 2009) while taking care that the message is not diluted or co-opted (Steady State Manchester, 2013). We are building up a core of people who can articulate Steady State thinking and working closely with influential groups and organisations. Through our series of reports, commentaries, blog posts, meetings, workshops and discussions we use research evidence to establish the validity of the approach, while recognising that ultimately this is not a battle that will be won by having "the best ideas and facts". We create temporary settings to explore ideas, maximising the "edge" (Kagan, 2007) between disparate sectors to generate new thinking and cooperation. We are thereby trying to build support for a counter-hegemonic model across sectors. All this work is underpinned by what would be recognisable as a community psychological set of assumptions, methods and values.

We have had some successes, being taken seriously by local green groups, anti-poverty campaigners, and local politicians with whom we are in dialogue. Some of our proposals have been adopted despite official rejection of our core message that continued growth of the economy is neither possible nor desirable.

\section{Problems we face}

Whatever our modest successes, we face an uphill struggle. Policy, politics and discourse is 'locked in' to the orthodox model, meaning that arguing for an alternative can still be met with incomprehension and horror. We are a small group fighting a hegemonic ideology that is broadly consistent across much of the political spectrum, fusing neoliberal economic rationalism with ecological ignorance in a highly plausible way, supported by the phantom abundance of global capitalism, the erosion of culture and the manufacture of insecure identity. So ideas get de-contextualised, distorted and then used to legitimate orthodox policy. This infects even supposedly, or once counter-hegemonic political movements. So in the the North, political parties (such as the UK Labour Party, the French Parti Socialiste, the Spanish PSOE, or Greek PASOK), whose original mission concerned economic justice, have mostly end up offering 'austerity lite' and the use of market mechanisms for pressing tasks like climate change mitigation (Lohmann, 2009). Meanwhile, in the South, reforming parties are wedded to an economic and social strategy based on extractivism (Gudynas, 2011; 2012): a form of dependence within the global accumulation regime. 


\section{Conclusion}

Community psychology has ignored the fundamental questions of planet and economy, that while macro-level in nature, impact on all levels from the global to the personal.

I hope to have shown that it is possible to intervene in local economies at municipal and regional levels, using community-psychological, or community-psychological-like approaches. However, while it is possible to build alliances, and influence thinking and practice, the dominant system is designed to resist these challenges in multiple ways, so it is essential that the relevant movements join together, learning from and supporting each other in the struggle for a better world, and for human survival itself.

\section{References}

Amin, S. (2010). The law of worldwide value. New York: Monthly Review Press.

Anderson, V. (1991). Alternative economic indicators. London; New York: Routledge.

Arnsperger, C., \& Varoufakis, Y. (2006). What Is Neoclassical Economics? The three axioms responsible for its theoretical oeuvre, practical irrelevance and, thus, discursive power. Real World Economics Review, (38). Retrieved from: http://www.paecon.net/PAEReview/issue38/ArnspergerVaroufakis38.htm

Burton, M. (2013). In and against social policy. Global Journal of Community Psychology Practice, 4(2). Retrieved from: http://www.gjcpp.org/pdfs/burtonv4i2-20130522.pdf

Chossudovsky, M. (2004). The Globalization of Poverty and the New World Order. Ottawa: Global Research.

D’Alisa, G., Demaria, F., \& Kallis, G. (Eds.). (2014). Degrowth: a vocabulary for a new era. Abingdon, Oxon ; New York, NY: Routledge.

Daly, H. E., \& Farley, J. (2011). Ecological economics : principles and applications. Washington, D. C.: Island Press.

Davies, W. (2009). Review essay: The making of neoliberalism. Renewal, 17, 88-92.
Deloitte (2008). "Mini-Stern" for Manchester: Assessing the economic impact of EU and UK climate change legislation on the North West and Manchester City Region. London: Deloitte. Retrieved from: http:// www.climatechangenorthwest.co.uk/resources/ greater-manchester-mini-stern-2008

Fatheuer, T. (2011). Buen Vivir a brief introduction to Latin America's new concepts for the good life and the rights of nature. Berlin: Heinrich Böll Foundation. Retrieved from: http://montreal2012.wordpress. com/2011/10/19/buen-vivir-a-brief-introductionto-latin-america\%E2\%80\%99s-new-concepts-forthe-g-ood-life-and-the-rights-of-nature/

Gorz, A. (2010). Critique of Economic Reason. London: Verso.

Grosfoguel, R. (2008). Transmodernity, border thinking, and global coloniality: decolonizing political economy and postcolonial studies. Eurozine. Retrieved from: http://www.eurozine.com/articles/2008-0704-grosfoguel-en.html

Gudynas, E. (2011). Debates sobre el desarrollo y sus alternativas en América Latina: Una breve guía heterodoxa. In M. Lang \& D. Mokrani (Eds.), Más allá del desarrollo. Quito: Fundación Rosa Luxemburgo, Abya Yala.

Gudynas, E. (2012). Estado compensador y nuevos extractivismos Las ambivalencias del progresismo sudamericano. Nueva Sociedad, (237), 128-146.

Harvey, D. (2010). The enigma of capital : and the crises of capitalism. Oxford [England], New York: Oxford University Press.

Haughton, G., Deas, I., \& Hincks, S. (2014). Making an impact: when agglomeration boosterism meets antiplanning rhetoric. Environment and Planning A, 46(2), 265-270. http://dx.doi.org/10.1068/a130335c

Henderson, H., \& Capra, F. (2009). Qualitative Growth. London: Institute of Chartered Accountants in England \& Wales.

Huanacuni Mamami, F. (2010). Buen Vivir / Vivir Bien: Filosofía, políticas, estrategias y experiencias regionales andinas. Lima, Peru: Coordinadora Andina de Organizaciones Indígenas - CAOI. Retrieved from: http://www.reflectiongroup.org/stuff/vivir-bien

Hinkelammert, F. J., \& Mora Jiménez, H. (2005). Hacia una economíapara lavida. San José, Costa Rica: Asociación Departamento Ecuménico de Investigaciones. 
Jackson, T. (2011). Prosperity without growth: economics for a finite planet. London; Washington, DC: Earthscan.

Kagan, C. (2007). Working at the "Edge": Making use of psychological resources through collaboration. The Psychologist, 20(4), 224-227.

Kagan, C., \& Burton, M. (2000). Prefigurative Action Research: an alternative basis for critical psychology? Annual Review of Critical Psychology, 2(73-87).

Kagan, C., \& Burton, M. (2014, july-sept.). Culture, identity and alternatives to the consumer culture. Educar Em Revista (Brazil), 53(Dossier: Educação, Cotidiano e Participação: desafios e contribuições para a formação). doi: http://dx.doi. org/10.1590/0104-4060.36583

Kagan, C., Burton, M., Duckett, P., Lawthom, R., \& Siddiquee, A. (2011). Critical Community Psychology. Chichester: Wiley.

Kagan, C., Lawthom, R., Knowles, K., \& Burton, M. (2000). Community Activism, Participation and Social Capital on a Peripheral Housing Estate. In European Community Psychology Conference. Bergen, Norway.

Kagan, C., Lo, S., Mok, L., Lawthom, R., Sham, S., Greenwood, M., \& Baines, S. (2011). Experiences of forced labour among Chinese migrant workers. York: Joseph Rowntree Foundation. Retrieved from: http://www.jrf.org.uk/publications/chineseexperiences-forced-labour

Latouche, S. (2012a). Can the Left Escape Economism? Capitalism Nature Socialism, 23(1), 74-78. doi: http://dx.doi.org/10.1080/10455752.2011.648841

Latouche, S. (2012b). Salir de la sociedad de consumo: voces y vías del decrecimiento ( $1^{\text {st }}$ Spanish edition.). Barcelona: Ocataedro.
Lohmann, L. (2009). When markets are poison: learning about climate policy from the financial crisis. London: The Corner House. Retrieved from: http://www. thecornerhouse.org.uk/resource/when-marketsare-poison

Mendoza, J, \& Zerda, M. (2011). Psicología comunitaria social en Bolivia. In M. Montero \& Serrano García, I (Eds.), Historias de la psicología en América Latina: participación y transformación (pp. 65-90). Buenos Aires: Paidós.

O'Neill, D. W. (2012). Measuring progress in the degrowth transition to a steady state economy. Ecological Economics, 84, 221-231. doi: http://dx.doi. org/10.1016/j.ecolecon.2011.05.020

Sánchez, E., Cronick, K., \& Wiesenfeld, E. (1988). Psychosocial variables and participation: A case study. In D. Canter, M. Kramping, \& D. Stea (Eds.), New Directions in Environmental Participation (pp. 1-17). Aldershot: Avebury.

Smith, P. B., \& Max-Neef, M. A. (2011). Economics unmasked: from power and greed to compassion and the common good. Totnes, Devon, UK: Green Books.

Steady State Manchester (2013, September 29). Good and bad growth? [Web blog]. Retrieved from: http:// steadystatemanchester.net/2013/09/29/good-andbad-growth/

Walker, C., Burton, M., Akhurst, J., \& Degirmencioglu, S. (2014). Locked into the system? Critical community psychology approaches to personal debt in the context of crises of capital accumulation. Journal of Community $\mathcal{E}$ Applied Social Psychology. doi: http://dx.doi.org/10.1002/casp.2209

Walker, C., \& Degirmencioglu, S. (Eds.). (in press). Social and Psychological Dimensions of Personal Debt and the Debt Industry. London: Palgrave Macmillan. 
